\title{
DEIXIS IN TAGLINES: \\ A SOCIO-CULTURAL SEMIOTIC ANALYSIS
}

\author{
Siti Nurani; Nico Harared
}

Department of English Education, Faculty of Language and Art, University of Indraprasta PGRI Jalan Nangka No. 58C Tanjung Barat, Jagakarsa, Jakarta Selatan 12530

rani_siti16@yahoo.com,nico.hrd@gmail.com

\begin{abstract}
The research aims at analyzing the socio-cultural semiotic that characterize the deixis in taglines. Such types of deixis are analyzed qualitatively by examining the socio-cultural functions using "Sign Mapping of Roland Barthes". The analysis focuses in describing the signifier and signified as well as the meaning of denotative and connotative characterized the deixis in taglines of various advertisements. Findings have shown that the signifiers and signified concepts function to inform, to challenge, to emphasize, and to persuade, of the consumers as the addressee. The types of deixis occur into such types of pronominals deixis (she, you, I, me), nominal deixis (girl, age, the city), verbal (blow, drive, come, follow, let, change), adverbial (in her face, anywhere, Marlboro country, when you can fly), and grammatical deixis (imperative, statement, interrogative). The denotative meaning is reflected from the use of signifiers that serves the real of sense of the product referred to, i.e., the commercial product that is divided into categories, man's category, woman's category, and unmarked category. The connotative meaning relates to some cultural values, such as pleasure, masculinity, feminity, passion, luck, beauty, freedom, and the sense of belonging.
\end{abstract}

Key words: socio-cultural semiotic analysis, deixis, tagline

\begin{abstract}
ABSTRAK
Tujuan dari penelitian ini adalah untuk menganalisis semiotik sosial budaya yang dikarakterisasikan dengan penggunaan deiksis pada tagline. Kategori deiksis akan dianalisis secara kualitatif dengan menganalisis fungsi sosial budaya "Petanda dan Penanda" Roland Barthes. Analisis pada penelitian ini terfokus pada penggambaran petanda dan penanda serta makna denotasi dan konotasi pada penggunaan deikis di setiap tagline di berbagai iklan. Hasil penelitian menunjukkan penggunaan konsep penanda dan petanda memiliki beberapa fungsi seperti menginformasikan, menantang, menekankan, dan membujuk konsumen sebagai partisipan. Kategori deiksis dalam penelitian ini diidentifikasikan ke dalam kategori deiksis pronomina (she, you, I, me), deiksis nomina (girl, age, the city), deiksis verba (blow, drive, come, follow, let, change), deiksis adverbia (in her face, anywhere, Marlboro country, when you can fly), and deiksis gramatikal (imperative, statement, interrogative). Makna denotative tergambarkan dari penggunaan penanda dan petanda dengan penggambaran nyata terhadap produk yang digambarkan ke dalam kategori produk pria, wanita, dan umum. Makna konotatif berkaitan pada beberapa nilai budaya seperti kesenangan, maskulinitas, feminitas, keinginan, keberuntungan, keindahan, kebebasan, dan rasa memiliki.
\end{abstract}

Kata kunci: analisis semiotik sosial budaya, deiksis, tagline 


\section{INTRODUCTION}

Lately the growth of technology goes to a very outstanding case since every mass media places many advantages for people in their lives. This is called as digital era where people have their ability to do everything in particular activity in business, such as to sell or to promote their products to the customers or the audiences. In this case, marketing strategy is needed. One of the strategies of marketing is through advertisements. We have ever wondered why brands spend so much to be heard and to be seen through TV commercials and newspaper nowadays. Hence, this is the power of advertisements to persuade publics, the action of making generally known to the attention of the public.

Advertisement is basically used to persuade public or audience. It is a means of communication with the users of a product or service. The attention of the audiences through advertisements is not easy to get as they have their own background, reason, taste and consideration to buy a product that is shown in media. The language used in advertisement has a great contribution in influencing the audience's mind to buy the products. In this case, advertisement must portray the advantages of the product as its selling point, not only through interesting language but also through the images in it. The language and images used in the advertisement should be an eye-ear catching as the audience or customer would interest to buy the products.

The language of advertisement releases in such variations that is based on the customers' need. The language of advertising is "Language in use with its characteristics such as simple, believable, readable, well connotated and adaptable" (Bollen, 1981:32). These characteristics refer to the qualification of advertising language with the form and messages in it. The way the advertisements serve the excitement of the products through language and images could be highlighted by using tagline. Tagline is a catchphrase or slogan, especially as used in advertising, or the punch line of a joke. Taglines can be used in marketing materials and advertising. The idea behind the concept is to create a memorable dramatic phrase that will sum up the tone and premise of an audio/visual product, or to reinforce and to strengthen the audience's memory of a literary product.

Tagline is usually seen with the company's name and logo. It can range from one to three short of sentences that are identified by the use of deixis. There are three main uses of tagline; first, it helps to convey the company's goal, value or unique selling preposition. Second, it helps to show brand personality; and third, it helps to differentiate company from competitors. In such countries with different sociocultural context would also bring different taglines in the sense of its demographic consent. In short, the advertiser must consider the sociocultural aspect of a community revealed by the taglines embodied in the advertisement.

Since we know the advantages of having a tagline, now there is one example of the common types of tagline. We may use them as a guide or inspiration. For example, the tagline, 'Because you're worth it' in the advertisement of L'OREAL PARIS consists of second person deixis 'you're', which refers to customer. It can be seen through its target oriented. It means that 'you're' refers to customer, since the customer sense of self-worth. Another example: "We make people fly" of Lion Air. In this tagline, 'We' in Lion Air's tagline represents the Lion Air company. Here, 'we' stands for the first 
person plural. The function of 'we' in this tagline to inform the audience that Lion Air is an air transportation company that has power to make 'people fly' in connotative meaning. From the two examples, it is clear that taglines represent the meaning that the advertisement conveys.

Semiotics could be referred as signs where the signs themselves represent information of things in such respects, such as the information about objects, events or even cultures. Every sign has its own background, particularly of the socio-cultural phenomena of a community. By such signs given from surroundings, semiotics takes place as a system that rules out the meaning emerged from those signs. Semiotics learns the systems, rules, conventions that mark those signs have meaning (Preminger, 2001). This means that every sign contributes to the judgment of meaning, and advertisement is one of the examples that serve various judgment of meaning form their audience.

The use of signs clearly reflects the meaning directly to the objects identified. As the meaning of advertisement is massively embodied from the use of taglines, deixis has the main role in characterizing its meaning, in this case, the meaning of products. In influencing the audience, the advertiser uses attractive and interesting language especially use deixis. For instance, in advertisement of cigarette is displayed in previous years ago, the advertiser uses "U are U" as tagline. Here, second person deixis 'you' in the letter $U$ is uttered as 'you', meanwhile people knew $\mathrm{U}$ as one of the letters. There are some reasons for using word in single letters, they are such as limited space and time, for example in writing SMS people tend to simplify the words into single letter in order to make it simple and eye catching. Then be up to date because here the advertiser uses this style to go along with the target of audience as teenagers. Here the functions of second person deixis to emphasize to identify as teenagers.

Deixis is pointing or indicating via utterance and relating to spatial-temporal situation. A deictic word or a word that has reference, which can be shifted and moved based on the speaker interpretation. Deixis in general divided in three types, namely: person deixis, time deixis and place deixis. Person deixis relates to personal pronouns, time deixis deals with the time utterance and place deixis concerns to the encoding of the location of the speaker reference in utterance. Essentially, the deictic expression can be used in two ways; they are gestural and symbolic ways. According to Levinson (1983) the gestural deictic can only be interpreted with referent to an audio visual tactile, and in general a physical, monitoring of speech event. The symbolic deictic is the deictic terms require for their interpretation on knowledge of the basic spatial-temporal parameters of the speech event.

Deixis deals with the connections among the situation, the speaker, place and time the world is uttered. Furthermore, Levinson (1983) also affirms that essentially deixis concerns with the ways in which languages encode feature of the context of utterance or speech event and thus also concerns with ways in which the interpretation of utterances depend on the analysis of that context of utterances. It means that deixis relates to language and context because the deictic word has reference based on the context of the language, which is uttered and the immediate context is with the speaker. Deixis is a word whose referent can change depending on the speaker's position and in one time and situation (Kaswanti, 1984). It means that deictic 
words are words with a reference point, which is determined by the speaker and his position in space and time.

The meaning of one sign is really influenced by another sign as the impact of the interplay of other elements, such as culture and social discourse. This will lead to the other sense of meaning itself, that is, additional meaning (connotative) and signified meaning (denotative). If all language phenomena are assumed to be signs, then socio-cultural semiotic analysis is assigned (Barthes in Sobur, 2009). As far as semiotic analysis is concerned, the socio-cultural aspect is intended to be analyzed as a major aspect of understanding the meaning, in this case, the meaning of the use of deixis that characterize the taglines in such advertisements.

Many scholars have carried out deixis analysis in some particular discussions. Some of them are Christopher (2012) and Samosir, et al. (2000). These scholars analyzed and investigated deixis analysis in such discussions, such "persuasive strategy" of deixis and personalization in advertising slogans by Christopher (2012); and "descriptive quantitative design" on deixis used in Jakarta Post by Samosir, et al. (2000).

Christopher (2012) implemented a study on deixis and personalization in advertisement slogan by using persuasive strategy. This research examines that the use of rhetorical or stylistic and linguistic strategy is widely used in advertising slogans for over a century. The findings show that there are five hundred advertising slogans of multinational companies in both product and service sectors. The findings reveal the three major aspects of this strategy as

\begin{tabular}{|l|l|}
\hline 1. Signifier & 2. Signified \\
\hline \multicolumn{2}{|l}{ 3. Denotative sign }
\end{tabular}

being deictic words, absolute uniqueness and personal pronouns. The findings also point that the use of persuasive strategy in creative ways held by advertisers could persuade consumers to buy their products and services.

Another research on deixis analysis was conducted by Samosir, et al. (2000) that concerned on the use of English deixis in the political article of Jakarta Post. The research used a descriptive quantitative design. The source of data was taken from the article of Jakarta Post with five articles are taken as the samples. The data is collected by using documentary technique. The findings showed that there are five types of deixis found, they are 99 person deixis $(42,85 \%)$; 43 time deixis $(18,61 \%) ; 42$ discourse deixis $(18,18 \%) ; 39$ social deixis $(16,88 \%)$; and 8 place deixis $(3,46 \%)$. The use of deixis functions to identify person interaction as it is seen from the type of person deixis as the dominant type of deixis found in this research.

\section{METHOD}

The focus of the research is on the analysis of the types of deixis used in taglines by examining its socio-cultural semiotic function. The data is analyzed by using "Sign Mapping" of Roland Barthes in Sobur (2009) to identify the socio-cultural semiotic function which derives from its signifier and signified social context, such as emphasizing, informing, persuading and challenging. Barthes in this case divides the steps of identification into two steps of significance, namely: first order (reality and signs) and second order (signs and culture). The analysis is conducted as follows: 


\begin{tabular}{|l|l|}
\hline 4. CONNOTATIVE SIGNIFIER & 5.CONNOTATIVE SIGNIFIED \\
\hline 6. CONNOTATIVE SIGN \\
\hline
\end{tabular}

The research approach employs a qualitative approach by examining the qualitative descriptive analysis. The research basically aims at aims analyzing the socio-cultural semiotic that characterize the deixis in taglines. The data the research is the deixis expressions of taglines (i.e., phrases and clauses) used in the commercial advertisements. The source of data is taglines originated in many cultures that are subdivided into three major categories seen from its interlocutors, namely: men's category, women's category, and unmarked category.

Such types of deixis are analyzed qualitatively to seek the interplay of socio-cultural semiotic functions used in taglines. The analysis of deixis is described, analyzed, and classified into several categories, namely: pronominals, nominals, verbal, adverbial and grammatical. The data is analyzed by using "Sign Mapping" of Roland Barthes to identify the socio-cultural semiotic function which derives from its signifier and signified social context, such as emphasizing, informing, persuading and challenging. Sign mapping in this research analyzes the relation of signifier and signified by the context of denotative, connotative and contexts occurred in each expression. The data (i.e., types of deixis and socio-cultural meaning) is analyzed, examined, classified, identified, and presented in the form of description which examines the interplay of socio-cultural aspects. The data analysis starts off by identifying the signifier and signified of the deixis. In this stage, the data is analyzed by examining the relation of signifier and signified of the signs toward the external reality. Then, the denotative sign of the deixis is analyzed by describing the way the objects are referred to the things in the real sense. Lastly, the analysis of connotative sign of the deixis is ascribed in accordance to the interaction when the signs meet the other element (i.e, feeling, emotion, as well as the cultural values of audience).

\section{RESULTS AND DISCUSSION}

1. Taglines of Man's Category

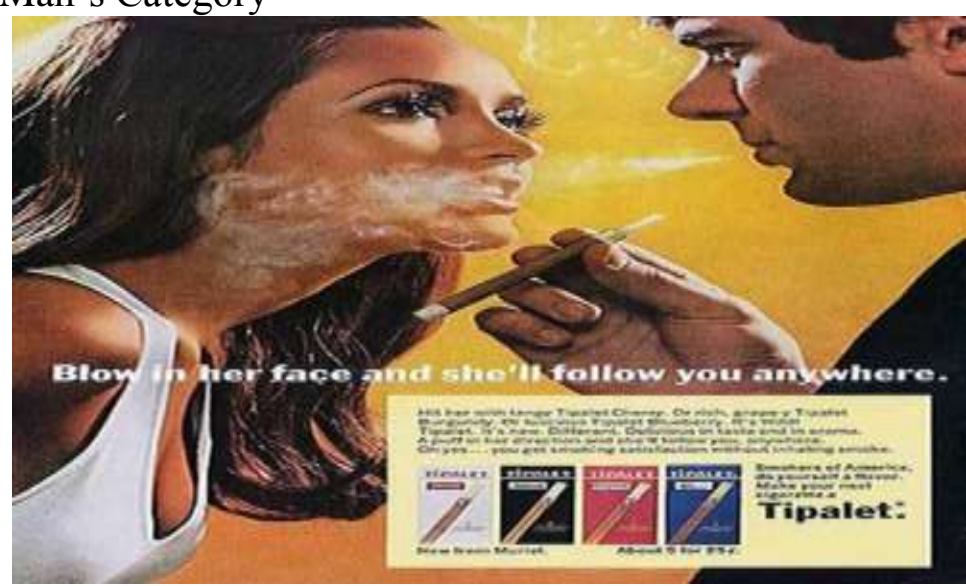

Figure 1,- Tipalet

"Blow in her face and she'll follow you anywhere" 
This ad consists of several signifiers, such as the picture of woman and man with cigarette's brand 'Tipalet', packs of cigarettes with many flavors and colors, as well as the tagline "blow in her face and she'll follow you anywhere". This ad is signified as the product of cigarette which serves many options of flavors for consumer to choose.

The denotative signs are reflected by the use of pictures and tagline. This ad reveals the pictures of man and woman with fume of smoke and packs of cigarette with four flavors. The pictures of man and woman reveal the interconnection between them. Here, the advertiser tries to persuade consumer to buy the product as the woman loves that product in particular as it is seen from the smiling woman's face when a man blows fumes in woman's face. Accordingly, the packs of cigarettes with many flavors and colors are also used by the advertiser to inform that the product serves many options of flavors for making the pleasure of consumers to choose.

Furthermore, other signifier is the use of tagline "blow in her face and she'll follow you anywhere". The tagline uses pronominal deixis, such as 'she' as the third singular person deixis which refers to the girl or woman and 'you' as the second plural person deixis that refers to consumer (i.e., smoker) that is mostly associated by man as the user; the adverbial deixis 'in her face' and 'anywhere' as the directional phrase in the sense of the goal for the user or smoker proves the best taste of the cigarette. The tagline precedes the expression by the use of verbal deixis 'blow' that is semantically meant to be as the imperative expression. Seen from its syntactical structure, the use of deixis in the tagline "blow in her face and she'll follow you anywhere", it is considered also as the grammatical deixis since the tagline forms the appropriateness of the arguments where the advertiser informs another 'second argument' by using imperative expression. With respect to the semiotic analysis, the advertiser uses these kinds of deixis to emphasize that if 'you' consumes this cigarette, in this case, the smoker (i.e, a man) will make 'she', in this case is the girl or woman will follow the smoker anywhere. Culturally, this tagline functions to challenge consumer to do as what as ad do since it gives representative of man who can interact a sexy woman. It means that when consumers use this product, they will attract the sexy woman easily.

As far as the socio-cultural semiotic analysis is concerned, the connotative meaning reveals that 'Tipalet' is a kind of cigarette that serves much pleasure for the smoker that is mostly associated by man as the user. Many ways to achieve the pleasure and one of the kinds is by doing activity that people like most. The man who smokes this cigarette represents as a figure of awesome, handsome, and masculine man. In the connotative meaning, the pleasure and masculinity seem to be the goal of everyone and are considered as the highest passion in the people's or man's lifestyle nowadays. In achieving something, people should give their best effort that is totally done by making such outstanding move physically and mentally. 


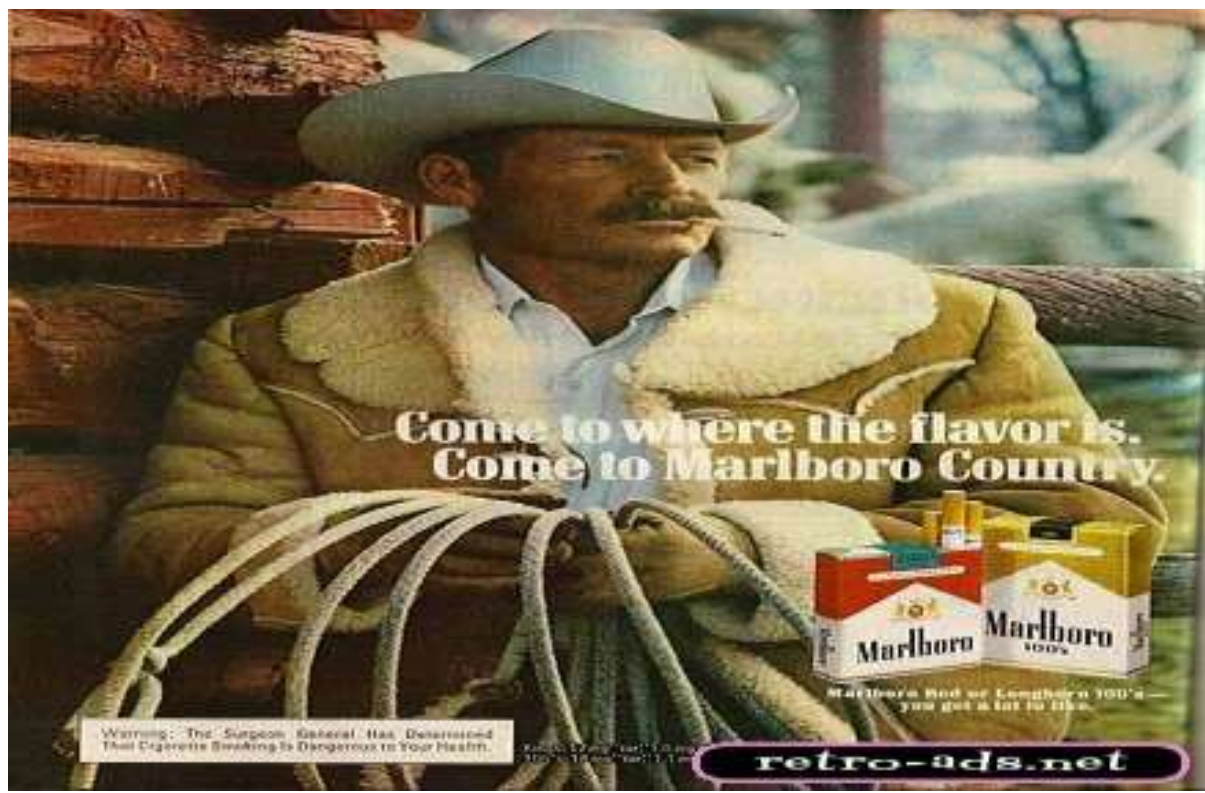

Figure 2,- Marlboro

"Come to where the flavor is. Come to Marlboro country"

This advertisement comprises of many signifiers, namely: the picture of old man with cigarette brand 'Marlboro', leather coat, rope and completed with cowboy hat, packs of cigarettes with two different flavors and colors, and also the tagline "Come to where the flavor is. Come to Marlboro country". This ad is signified as the product of cigarette which serves such tastes for consumer.

The use of pictures and tagline represents the denotative signs. Seen from the point of view of the pictures, this ad reveals the figure of a man in Marlboro country with the attributes of "country-like". In this case, the advertiser uses the symbol of culture in a country to persuade consumers to buy the product as they can feel like "at home" or "at the country" if they smoke Marlboro as it is seen from the background of the country which serves a peaceful sightseeing. Another pictures used are two packs of different flavors of cigarettes that function to inform consumers that Marlboro has also colorful tastes.

The use of tagline is other signifier found in this ad. The tagline "Come to where the flavor is. Come to Marlboro country" is preceded by the use of verbal deixis "come" followed by the adverbial deixis "where the flavor is" and "Marlboro country" that is considered as imperative expression by the absence of the use of pronominal deixis. With respect to the semiotic analysis, the advertiser uses these kinds of deixis to persuade the consumer to buy this cigarette. Culturally, this tagline functions to inform consumer to smoke Marlboro since it serves the best taste of peaceful like in a country's life. Here, the advertiser wants to invite the consumer over to feel and to taste the nature of country.

The connotative meaning is reflected from the sense that 'Marlboro' is a kind of cigarette that gives peaceful taste for the smoker as the nature of country serves. The pure nature influences people for doing something good in their life. Bad things will be subsided if people have a positive thought to live their life in a more humane way. A peaceful savor is created by the people who also love peace. By the end of the time, people will miss the 
peaceful place where they belong to be, that is "a home" or "a country". Therefore, people should paint their love to such peaceful places as the peace comes. People should take care of the nature for their goodness.

2. Taglines of Woman's Category

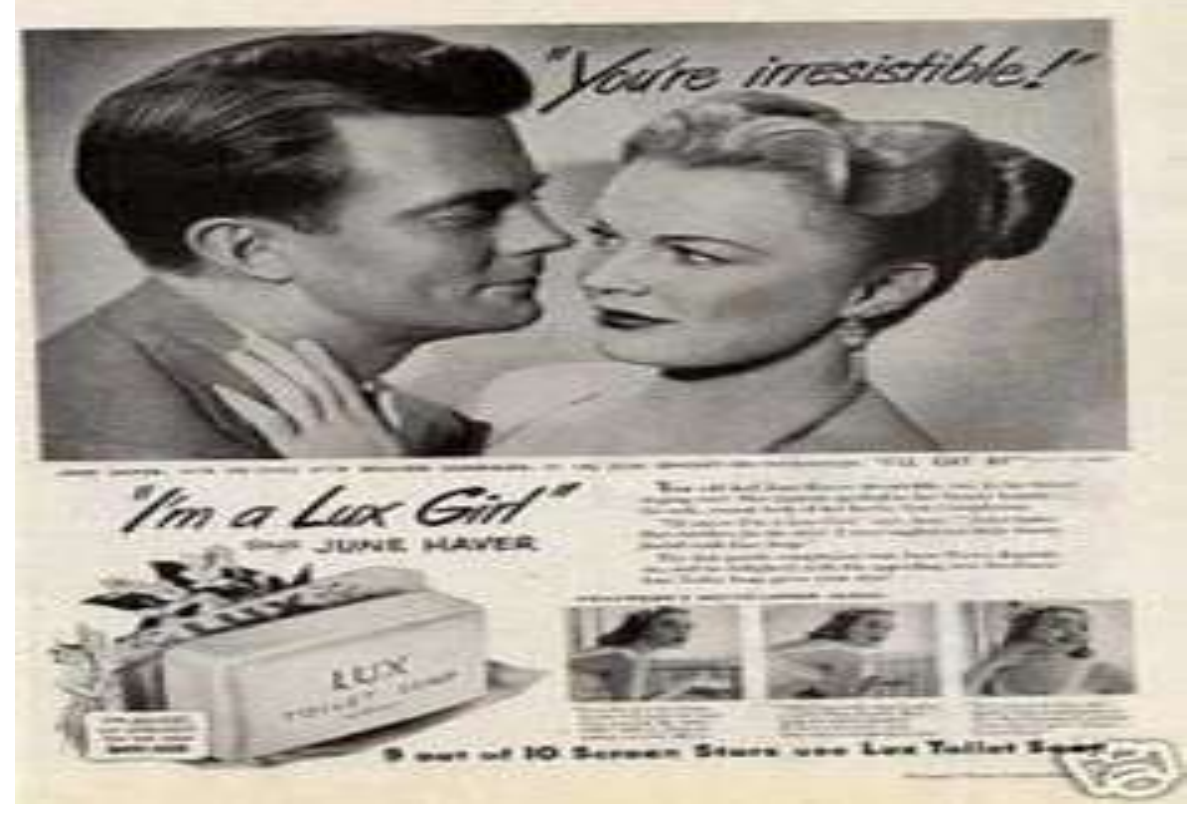

Figure 3,- Lux

"You're irresistible! I'm a Lux Girl"

Several signifiers are identified in this ad, they are the picture of a romantic couple, three other pictures of girls, and the tagline "You're irresistible! I'm a Lux Girl". This ad is signified as the product of soap which offers luxurious experience in bathing.

Denotative meaning is derived from the use of pictures as well as the tagline. The picture of a romantic couple that is signified by the handsome man and a pretty girl persuades consumers to use this product as they will also get romantic experience as the couple show. Also, the three other pictures of girls with beautiful skin inform consumers to take the product as their need.

Another signifier identified in this $\mathrm{ad}$ is the use of tagline "You're irresistible! I'm a Lux Girl'. The tagline expresses the consumer's feeling of using the soap "Lux". Here, the feeling is described as positive and enthusiastic as shown from the words "irresistible" and "lux" that also could be referred to the word "luck" in particular sense. In this tagline, the advertiser uses pronominal deixis "you" as the second plural person deixis; " $I$ " as the first singular person deixis; and the use of nominal deixis "Girl" as the third singular person deixis. The use of the deixis "you" refers to the soap that makes the girl feels irresistible just after she takes a bath with it. The fragrance of the soap will attract everyone's attention (particularly man) to the user (i.e., girl). Whereas the use of the deixis "I" identifies the user herself by saying with full confidence that she becomes a luck girl to use the soap as it is reflected by the man who stares at the girl aggressively. Culturally, this tagline functions to inform consumers (i.e., girls) to use as many girls in the world will become "luck girls" if they use the 
product.

The word "luck" seems to be as the connotative sense in this advertisement. No luck is gained by no effort. The success will never be attained if people give no effort in doing its process. By only hoping for the "luck" as one of the factors of achieving the success, people will not pay "a hard-working" oriented for more. Therefore, people have to change their mind that "luck" is only one of the external factors of the success since it is believed that only by praying and working hard will take people to the real success both in the world and in the life after.

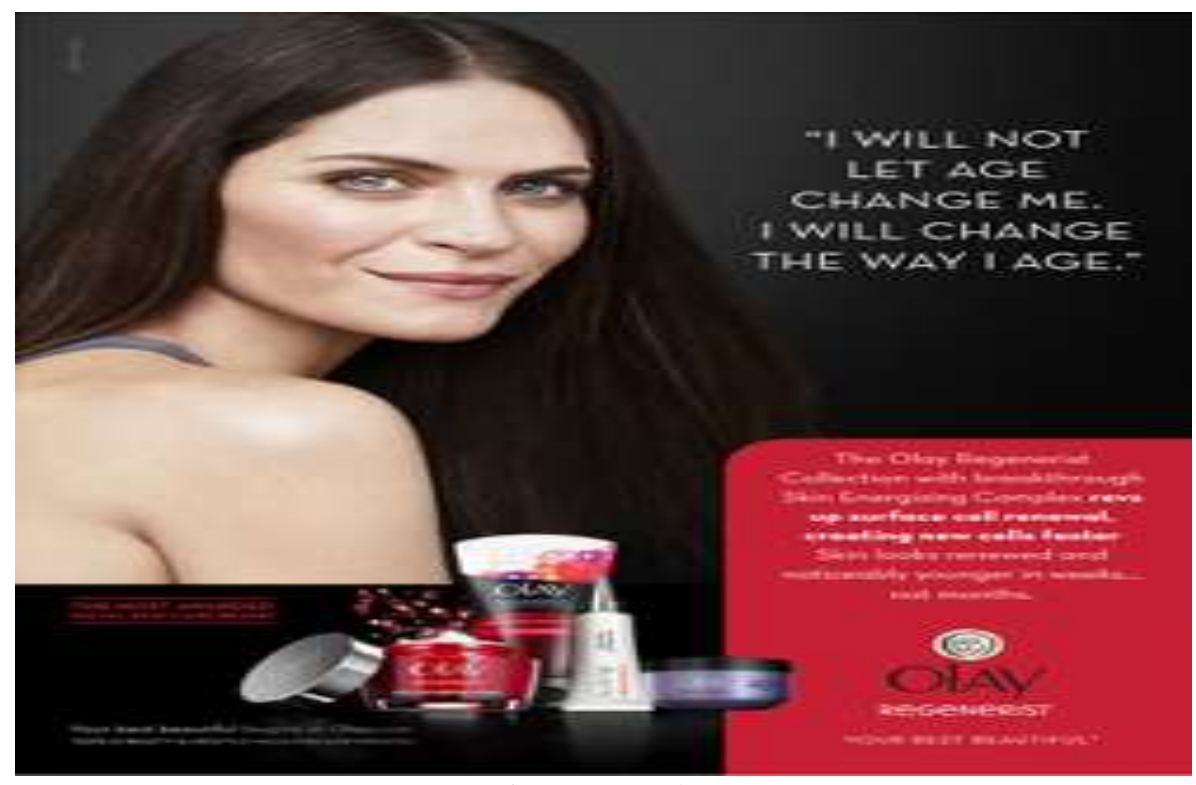

Figure 4,- Olay

"I will not let age change me. I will change the way I age.

There are various signifiers marked in this advertisement, such as the picture of a woman, cosmetics, as well as the tagline "I will not let age change me. I will change the way I age". This ad is signified as the product of cosmetic which guarantees woman a long-lasting beauty.

The denotative meaning is reflected from the use of pictures as well as the tagline. The picture of a woman with beautiful skin persuades consumers to use this product to get their look as same as the woman's. The figure of cosmetic "Olay" with colorful and attractive shapes serves many choices of its function. Also, the brand "OLAY" which is written in capital and highlighted in black color makes consumer easily to remember the name of the brand.
Moreover, the other signifier is the use of tagline "I will not let age change me. I will change the way I age". This tagline uses pronominal deixis, namely: "I" as the subjective pronoun of a first singular person deixis; "me" as the objective pronoun of a first singular person deixis; and the use of nominal deixis "age". Also, the use of verbal phrases deixis, such as "will not let" and "will change", functions to inform consumers in convincing themselves to use the product. Semantically, the expression "I will not let age change me. I will change the way I age" challenges consumers to change their mind about the age. That age will be only a matter of number which is not a big problem for them as long as they use the product. Syntactically, the tagline "I will not let age change me. I will change the way I 
age" forms an appropriate order of arguments (i.e., the order of noun and verb), hence, it can be said that the tagline is considered as grammatical deixis.

Having had a long lasting beauty is a dream of everyone particularly for women in common. Outer beauty is only a matter of physical adjustment that everyone must face in the phase of life as a border line of becoming old physically. Meanwhile, the inner beauty connotatively plays as a long-lasting beauty for everyone. Be natural with no "masks" in a face will lead someone to the true meaning of beauty; beauty of thought, beauty of belonging and beauty of loving, beauty of giving, and beauty of taking care of others. There will be no measurement and border line of this kind of beauty as it mentally lives in someone's heart for good. The inner beauty helps people find positive ways to go through the life for being a meaningful person for others.

\section{Taglines of Unmarked Category}

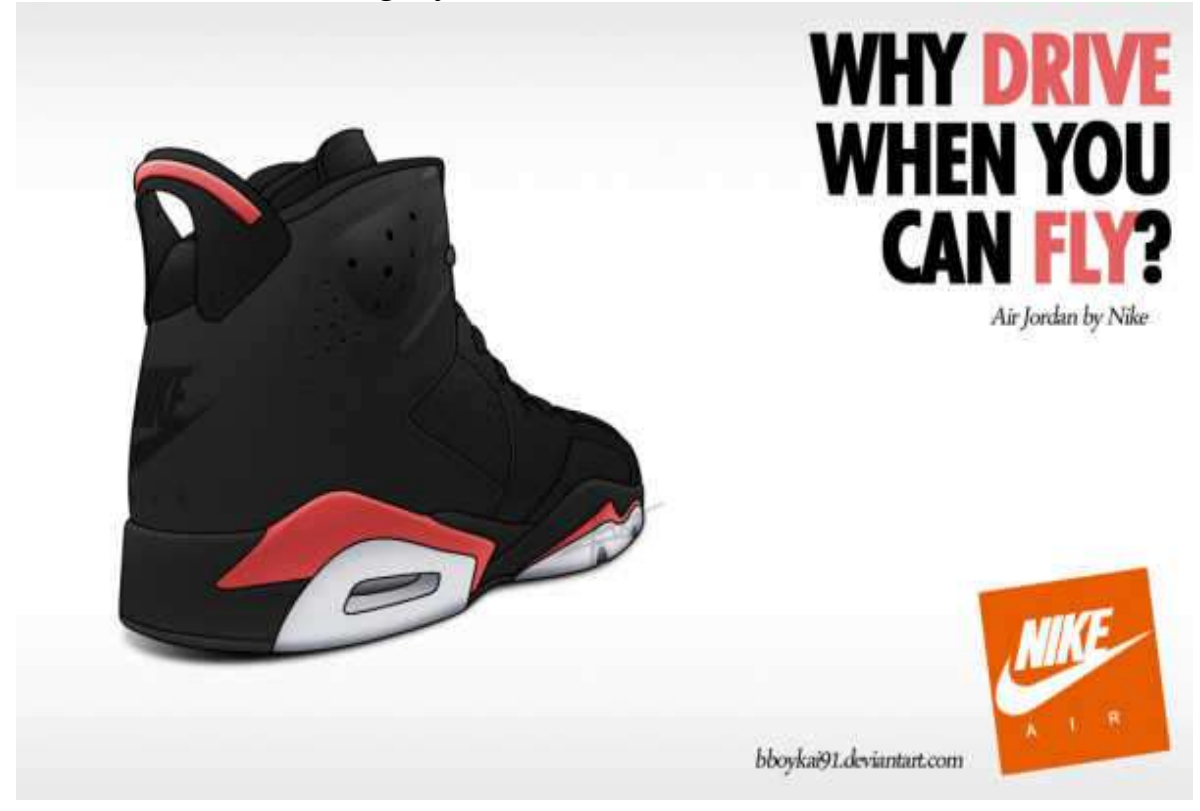

Figure 5,- Nike

"Why drive when you can fly?"

The signifiers used in this ad reveal to the picture of black-red shoe with famous brand NIKE and also the tagline "Why drive when you can fly?" This ad is signified as the product of shoes which serve comfortable for the user.

Denotative signs show the relation between the use of picture and its tagline. The picture of shoe is described as tough, dynamic, with elegant and stylish shape functions to emphasize consumers that the shoe is the best shoe of the kinds, seen from its style and shape. Moreover, the brand "NIKE" which is written in capital and highlighted in white color makes consumer easily to remember the brand.

Furthermore, the use of tagline in the form of question "Why drive when you can fly? " functions to challenge and to persuade consumers to feel the taste of freedom as bird flies in the sky. The word "DRIVE" and "FLY" are typed in capital, highlighted by red color with the expression "Air Jordan by Nike" that refers to the name of the shoe. Such 
expressions emphasize consumers that by using the "Air Jordan" shoe by Nike, they will go faster as semantically derived from the meaning that "fly" in the air is faster that "drive" on the road. The shoe is described as light as flying object but tough in size.

The tagline "Why drive when you can fly? " uses pronominal deixis, that is, "you" as the second plural person deixis. The use of verbal deixis "drive" in the question form is also identified in this tagline which functions to persuade consumers to take part of using the shoe. As far as the grammatical relation is concerned, this tagline fulfills the condition of grammatical deixis since the expressions "Why drive when you can fly?" forms an appropriate order of arguments in the question form of complex sentence (i.e., the order of whquestion marker, verb and adverbial clause).

Freedom as it is served by the product contains connotative meaning as the way people look their life freely without a pressure and limit. The way people think, the way they speak, the way they argue, as well as the way they behave as will be as "their belonging" to the way they do the living. Freedom in this sense should play as the positive path for people to walk around their living. There is still, however, norms and cultural values of life would be the best escorts to balance people's mind to do something positive by its freedom. The term Freedom could be best described as "free with wisdom". Take the freedom as we take it as wisdom.

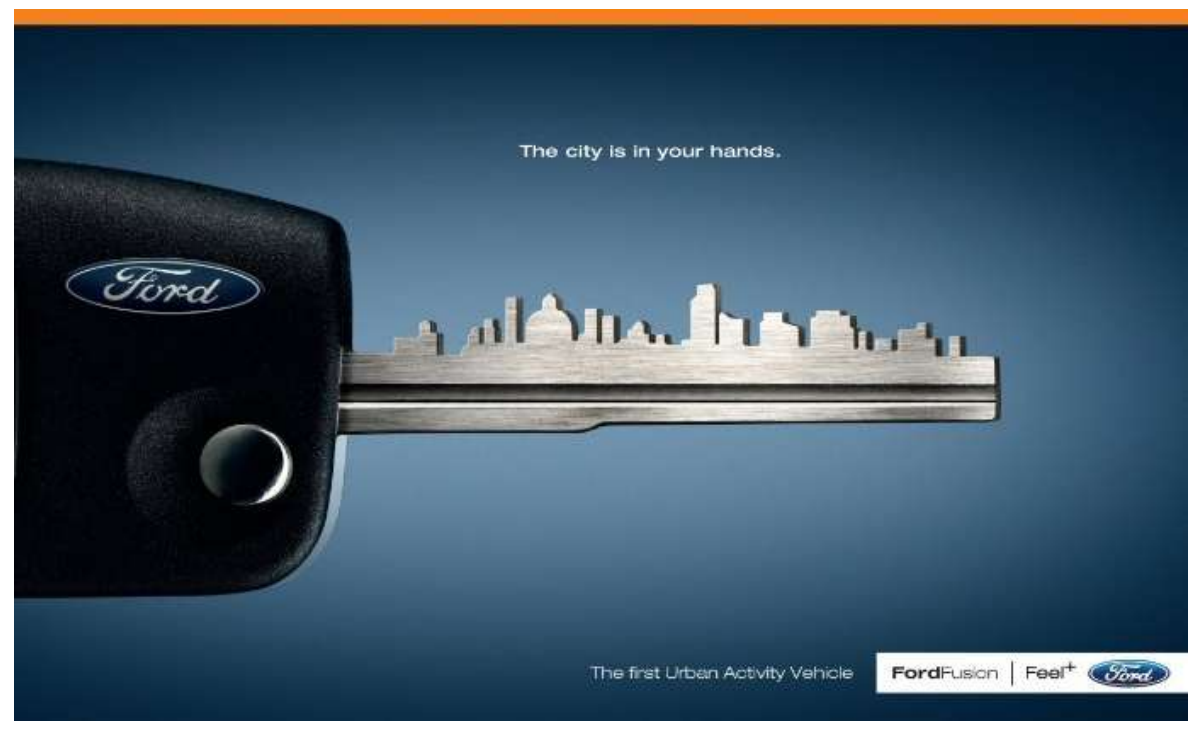

Figure 4.6,- Ford

"The city is in your hands"

The use of the figure of the key with silhouette of the city named "Ford", the expression "The first Urban Activity Vehicle", and the tagline "The city is in your hands" are the signifiers of this advertisement which signify the product of vehicle for urban people to have.

The denotative meaning is reflected from the use of those above signifiers. The figure of the key with silhouette of the city named "Ford" emphasizes consumers to have "Ford" as the vehicle for urban people for the key presents high buildings as in the city's sightseeing. The expression "The first Urban Activity Vehicle" implies that no vehicle that is best driven by urban people around the city but "Ford". It 
functions to inform as well as to persuade consumers that there is no doubt for them to have such excellent vehicle.

Other signifier, the tagline "The city is in your hands", is used by the advertiser to emphasize as well as to challenge consumers to drive "Ford" as they will have an easy-great experience in driving even in the traffic jam of the city's bustle. The tagline "The city is in your hands" employs the use of nominal deixis, that is, "The city" followed by the use of possessive pronominal "your hands" is a kind of statement which functions to inform consumers to have Ford as they will also "have" the city. Seen from its structure, the tagline is said to have grammatical deixis as the tagline forms an appropriate order of arguments in the statement of a simple sentence (i.e., the order of noun phrase, verb and adverb).

Connotatively, the tagline emphasizes the sense of belonging of something. This kind of sense would be as everyone's need of all. Therefore, in achieving something people should employ positive ways to attain positive result. The sense of belonging something would be considered as the motivator for people to do the something by hardworking, even the worst thing comes into.

\section{CONCLUSION}

It is widely believed that the use of deixis in taglines is an effective and efficient way for advertisers to ease the promotion of their products. The signifiers assigned in the advertisements are the use of pictures as well as the use of deixis in taglines as they signify the basic concept of each product. The use of pictures as well as deixis which characterizes the taglines serves into several functions of language, namely: to inform, to challenge, to emaphasize, and to persuade. In this case, all those functions of language are addressed to consumer. The types of deixis occur into such types of pronominals deixis (she, you, I, me), nominal deixis (girl, age, the city), verbal (blow, drive, come, follow, let, change), adverbial (in her face, anywhere, Marlboro country, when you can fly), and grammatical deixis (imperative, statement, interrogative). The denotative meaning is reflected from the use of signifiers that serves the real of sense of the object referred to, i.e., the commercial product that is divided into categories, man's category, woman's category, and unmarked category). The connotative meaning relates to some cultural values, such as pleasure, masculinity, feminity, passion, luck, beauty, freedom, and the sense of belonging.

\section{REFERENCES}

Bollen, W. H. (1981). Advertising. New York: John Wiley and Sons.

Christopher, A. A. (2012). Deixis and personalization in ad slogans, International Journal of Social, Behavioral, Educational, Economic, Business and Industrial Engineering, 6(4), 517-521.

Kaswanti, P. B. (1984). Deiksis Dalam Bahasa Indonesia. Jakarta: Balai Pustaka.

Levinson, S. (1983). Pragmatics. Cambridge: Cambridge University Press.

Preminger, A, et al. (ed.). (2001). Semiotik (Semiologi) dalam Jabrohim (ed.). Metodologi Penelitian Sastra. Penerjemah rahmat Djoko Pradopo. Yogyakarta: Hanindita Graha Widia. 
Samosir, N. B., \& Zainuddin (2000). An Analysis of Deixis in the Article of the Jakarta Post. (Unpublished thesis). State University of Medan (UNIMED), Indonesia.
Sobur, A. (2009). Analisis Teks Media.

Bandung: PT. Remaja

Rosdakarya 